\title{
Cardioprotective Potential of Methanol Extract of Costus Afer Leaf on Carbon Tetrachloride-Induced Cardiotoxicity in Albino Rats
}

\author{
U. O. Njoku*, O. F. C. Nwodo and M. O. Ogugofor \\ Pharmacology and Toxicology Unit, Department of Biochemistry, University of Nigeria, \\ Nsukka; ugochi.njoku@unn.edu.ng
}

\begin{abstract}
Costus afer leaf extract is one of the native heritages of folklore medicine in Nigeria, used for the treatment of various disease conditions. Therefore this study was undertaken to evaluate the cardioprotective potential of the methanol extract of Costus afer leaves on $\mathrm{CCl}_{4}$ - induced cardiotoxicity in albino rats. Twenty-eight (28) albino rats were divided into four main groups: normal control (normal saline only), $\mathrm{CCl}_{4}$ control (saline and $\mathrm{CCl}_{4}$ ), aspirin treated (1.2 mg/kg b.w aspirin and $\mathrm{CCl}_{4}$ ) and Costus afer extract treated (extract and $\mathrm{CCl}_{4}$ ) groups. Costus afer extract was administered in four doses; $100,200,300$, and $400 \mathrm{mg} / \mathrm{kg}$ b.w. p.o for 7 days. On day $7, \mathrm{CCl}_{4}(2.5 \mathrm{ml})$ cardiotoxicity was induced in animals of $\mathrm{CCl}_{4}$ control, aspirin treated and extract pre-treatment groups. The parameters studied in this respect were cardiac biomarker enzymes; Creatine Kinase (CK), Aspartate Transaminases (AST) and Lactate Dehydrogenase (LDH), serum lipid profile; Triacylglycerol (TAG), Total Cholesterol (TC), Low Density Lipoprotein (LDL), High Density Lipoprotein (HDL) and artherogenic index (AR), lipid peroxidation; malondialdehyde (MDA) level and enzymatic antioxidant levels of cardiac tissue homogenate; Superoxide Dismutase (SOD), Catalase (CAT) and Glutathione Reductase (GR). $\mathrm{CCl}_{4}$ intoxication produced significant $(\mathrm{p}<0.05)$ increases in cardiac biomarker enzymes, serum lipid profile (TAG, TC, and LDL) along with enhanced lipid peroxidation in heart, while significant $(\mathrm{p}<0.05)$ decreases in enzymatic antioxidant activities and HDL contents were also observed when compared to normal control. Costus afer leaf extract protected against $\mathrm{CCl}_{4}$ cardiotoxic effect by restoring the cardiac functions alterations, augmenting antioxidant activities, reducing lipid peroxidation and improving lipid profile levels near normal. From the results, Costus afer leaves expressed cardioprotective potential and could be helpful in the management of cardiac dysfunction.
\end{abstract}

Keywords: Antioxidant Activity, Cardiotoxicity, Costus Afer, Carbon Tetrachloride, Myocardial Infarction

\section{Introduction}

During, the last decade, the use of traditional medicine has expanded globally and is gaining popularity ${ }^{1}$. According to the World Health Organization, herbal medicines serve the health needs of about $80 \%$ of the world's population, especially for millions of people in the vast rural area of developing countries ${ }^{2}$. In Nigeria, many indigenous plants are used as sources of affordable medicine, food and spices, and are regarded as powerful therapeutic agents due to their pharmacological activities.

Myocardial Infarction (MI) is a chemical problem defined as acute necrosis of the myocardium that occurs so as a result of imbalance between coronary blood supply and myocardial ${ }^{3}$. It is well recognized that free radicals generated in ischemic tissues cause metabolic stress which results in degradation of tissue defence system leading to myocardial damage and necrosis ${ }^{4}$. Herbal antioxidants may protect against these diseases by contributing to the total antioxidant defence system ${ }^{5,6} . \mathrm{CCl}_{4}$ is a renowned model compound for producing chemical tissue toxicity by creation of free radicals in liver, kidney, heart, lung, testis, brain and blood ${ }^{7}$. $\mathrm{CCl}_{4}$ intake is followed by transformation in the liver by cytochrome $\mathrm{P}_{450}$ leading

* Author for correspondence 
to the formation of trichloromethyl free radical $\left(\mathrm{CCl}_{3}\right.$ or $\mathrm{CCl}_{3} \mathrm{OO}$ ) which could modify molecular probably lipids, leading to peroxidation of polyunsaturated fatty acids in the cell membrane ${ }^{8}$. The antioxidant activity or the inhibition of the generation of free of radicals is important in providing protection against myocardial infarction ${ }^{8}$. Natural products derived from plant extracts/fraction are novel therapeutic agents for various infections as well as degenerative diseases? ${ }^{9}$.

Costus afer is commonly called "Gingerlily" or "Bush cane". In Nigeria, it is called "Ireke omode" in Yoruba, "Okpete" in Igbo, "Kakizawa" in Hausa, "Mbritem" in Efik and Anglophone Cameroon calls it "Monkey sugar cane"10. Costus afer is an indigenous West African medicinal plant of the family of Zingiberaceae. It is one of the 150 species of stout, perennial and rhizomatous herbs that grow in moist or shady forests and river banks ${ }^{11}$. Researchers have reported that Costus afer leaves extract is antitussive, hypoglycaemic, immunomodulatory, antimalaria ${ }^{12-15}$. Godswill et al. ${ }^{16}$ reported that an infusion of Costus afer inflorescence and rhizome is taken to treat leprosy and veneral diseases. According to Taiwo and Bolanle, aqueous and methanol extract of Costus afer stem exhibited antioxidant activity in vitro ${ }^{17}$.

Furthermore, Omokhua reported that Costus afer is used for other socio-cultural purposes such as preparation of ritual ornaments, wrapping of indigenous foods, mat making and as feed for ruminant animals ${ }^{15}$. The effect of Costus afer leaf extract on myocardial antioxidant defense system in $\mathrm{CCl}_{4}$ induced myocardial necrosis has not yet being studied. Therefore, the present study was conducted to examine the beneficial effects of Costus afer leaf extract on heart tissue in $\mathrm{CCl}_{4}$-induced cardiotoxicity in rats.

\section{Materials and Methods}

\subsection{Collection of Costus afer Leaves}

Fresh leaves of Costus afer collected from Ozom Mgbagbu-Owa in Ezeagu Local Government of Enugu State were identified by Mr. Alfred Ozioko of Bioresources Development and Conservation Programme, Nsukka, Enugu State, Nigeria.

\subsection{Preparation of Plant Material}

The Costus afer leaf were washed with distilled water, airdried at room temperature and pulverized into powder for extraction. The powder (500 g) was extracted in 1.5 $\mathrm{L}$ of methanol and allowed to stand for $48 \mathrm{hrs}$ at room temperature. The mixture was filtered with Whatman No. 4 filter paper and the filtrate was concentrated using rotary evaporator to get a semi solid extract.

\subsection{Phytochemical Screening}

The screening for some chemical constituents of the plant leaf extract was carried out as described by Harbone, and Trease and Evans. ${ }^{18,19}$. Quantitative analysis was carried out as described by Harbone, and Soni and Sosa ${ }^{20,21}$.

\subsection{Assessment of Cardio Protective and Antioxidant Properties}

\subsubsection{Animals}

Twenty eight (28) adult male albino rats, weighing 120-200 $\mathrm{g}$ were obtained from the animal house of the faculty of Veterinary Medicine, University of Nigeria, Nsukka. The animals were kept in clean aluminium cages placed in a well-ventilated house under standard laboratory condition of temperature at $25 \pm 2{ }^{\circ} \mathrm{C}$, relative humidity of $55 \pm 10$ $\%$, and light: dark cycle of $12 \mathrm{hr}$ photoperiod. All the rats were allowed free access to rat pellet and water before and throughout the experiment. The rats were handled according to the guidelines of the National Institute of Health on the case and use of laboratory animals

\subsubsection{Treatment Protocols}

A total of twenty eight (28) rats were used and randomly divided into seven (7) main experimental groups (A$\mathrm{G})$, each containing four (4) animals. After one week of acclimatization, $1.2 \mathrm{mg} / \mathrm{kg}$ b.w of aspirin and different doses of the extracts were orally administered to groups C and D - G respectively while groups A and B received distilled water for seven (7) consecutive days.

\subsubsection{Inducement of Cardio toxicity}

Cardio toxicity was induced according to the method described by Agbafor et al2 . Briefly, on the seventh day, two hours after the extract or aspirin administration, groups B - G were treated with a single dose of $2.5 \mathrm{ml} / \mathrm{kg}$ b.w of $\mathrm{CCl}_{4}$ and olive oil (1:1) intraperitoneally. Group A was given distilled water/olive oil (1:1).

Summary of groups and treatment: 
Group A: Normal saline

Group B: $\mathrm{CCl}_{4}$ only

Group C: $1.2 \mathrm{mg} / \mathrm{kg}$ b.w aspirin $+2.5 \mathrm{ml} / \mathrm{Kg}$ b.wt $\mathrm{CCl}_{4}$

Group D: $200 \mathrm{mg} / \mathrm{kg}$ b.w of methanol leaf extract +2.5

$\mathrm{ml} / \mathrm{kg}$ b.wt $\mathrm{CCl}_{4}$

Group E: $400 \mathrm{mg} / \mathrm{kg}$ b.w of methanol leaf extract $+2.5 \mathrm{ml} /$ $\mathrm{kg}$ b.wt $\mathrm{CCl}_{4}$

Group F: $600 \mathrm{mg} / \mathrm{kg}$ b.w of methanol leaf extract $+2.5 \mathrm{ml} /$ $\mathrm{kg}$ b.wt $\mathrm{CCl}_{4}$

Group G: $800 \mathrm{mg} / \mathrm{kg}$ b.w of methanol leaf extract +2.5 $\mathrm{ml} / \mathrm{kg}$ b.wt $\mathrm{CCl}_{4}$

\subsubsection{Collection of Blood Sample from Experimental Animals}

Blood samples were collected from the experimental animals using the method described by Agbafor et a $l^{22}$. Briefly, blood samples were collected from the animals following an overnight fast through cardiac puncture under mild anaesthesia using chlorofor] $\mathrm{m}$. The samples were put into specimen bottles without anticoagulant. Heart was also quickly excised, perfused with cold normal saline and homogenized in $0.25 \mathrm{M}$ sucrose in phosphate buffer (0.2 M, pH 7.4).

\subsubsection{Cardio Protective Property}

Cardio protective effect of the extract was studied by determining the serum levels of CK, LDH, AST and lipid profile (Total cholesterol, TAG, HDL and LDL). The methods as contained in the respective kits (Randox kits, UK) of the parameters were adopted.

\subsubsection{Biochemical Studies}

Heart tissues were homogenized in $\mathrm{KCl}(10 \mathrm{nM})$ phosphate buffer $(1.15 \%)$ with ethylene diaminetetracetic acid (EDTA, pH 7.4) and centrifuged at $12000 \mathrm{rpm}$ for 20 minutes. Aliquot was used for biochemical estimation.

\subsubsection{Antioxidant Activity}

This was evaluated in the heart homogenate by estimating the concentration of MDA, a stable product of lipid peroxidation according to the method described by Ohkawa et al. ${ }^{23}$ Myocardial activity of SOD, CAT and GR were determined by the method of Kakkar et al.; Aebi; and Bentler respectively ${ }^{24-26}$.

\subsection{Data Analysis}

Statistical analysis was done using analysis of variance (ANOVA). Means were compared for significance using Duncan's Multiple Range Test $(\mathrm{p}<0.05)$.

\section{Results}

\subsection{Percentage Yield}

Costus afer leaf yielded $30.48 \mathrm{~g}$ of the extract which represents $4.79 \%$ of the starting material.

\subsection{In Vitro Study}

Preliminary phytochemical screening for some chemical constituents of the extract of Costus afer leaf is shown in Table 1.

Table 1. Some chemical constituents of the Costus afer leaf extract

\begin{tabular}{lc}
\hline Phytochemical Constituents & Concentration \\
\hline Alkaloids $(\mathrm{mg} / \mathrm{g})$ & $2.67 \pm 0.35$ \\
Flavonoids $(\mathrm{mg} / \mathrm{g})$ & $3.53 \pm 0.31$ \\
Tanins $(\mathrm{mg} / \mathrm{g})$ & $1.39 \pm 0.40$ \\
Saponins $(\mathrm{mg} / \mathrm{g})$ & $2.29 \pm 0.19$ \\
Terpenoids $(\mathrm{mg} / \mathrm{g})$ & $6.24 \pm 0.13$ \\
Glycosides $(\mathrm{mg} / \mathrm{g})$ & $5.28 \pm 0.16$ \\
Phenolics $(\mathrm{mg} / \mathrm{g})$ & $4.87 \pm 0.14$ \\
Sterols $(\mathrm{mg} / \mathrm{g})$ & $2.52 \pm 0.71$ \\
\hline
\end{tabular}

\subsection{Effects of Costus afer Leaf Extract on Cardiac Function Test on Rats}

$\mathrm{CCl}_{4}$ intoxication markedly increased the concentration of $\mathrm{CK}, \mathrm{LDH}$ and AST relative to the control group. Administration of the graded doses of the extract significantly $(\mathrm{p}<0.05)$ decreased the concentration of these enzymes near normal in a dose dependent manner, ameliorating the toxic effect of $\mathrm{CCl}_{4}$ as compared to the rats treated with $\mathrm{CCl}_{4}$ only. Significant $(\mathrm{p}<0.05)$ decreases in the concentration of the enzymes were also observed in the group that received the standard drug. At the highest tested dose of $800 \mathrm{mg} / \mathrm{kg}$ b.w, Costus afer leaf extract significantly $(\mathrm{p}<0.05)$ suppressed the toxic effect of $\mathrm{CCl}_{4}$ more effectively relative to the standard drug. 
Table 2. Serum levels of CK, LDH and AST

\begin{tabular}{lccc}
\hline Group & CK (U/L) & LDH (U/L) & AST (IU/L) \\
\hline Normal Control & $110.30 \pm 3.13^{\mathrm{b}}$ & $134.00 \pm 3.65^{\mathrm{a}}$ & $170.90 \pm 4.15^{\mathrm{a}}$ \\
$\mathrm{CCl}_{4}$ only & $378.20 \pm 8.63^{\mathrm{f}}$ & $265.25 \pm 1.71^{\mathrm{f}}$ & $286.18 \pm 3.40^{\mathrm{f}}$ \\
$1.2 \mathrm{mg} / \mathrm{kg}$ & $102.62 \pm 2.98^{\mathrm{ab}}$ & $148.252 .06^{\mathrm{b}}$ & $205.11 \pm 1.44^{\mathrm{b}}$ \\
Standard Drug & & & \\
(aspirin) $+\mathrm{CCl}_{4}$ & & & \\
$200 \mathrm{mg} / \mathrm{kg} \mathrm{b} . w t$ & $277.08 \pm 12.79^{\mathrm{e}}$ & $234.25 \pm 2.21^{\mathrm{e}}$ & $251.53 \pm 1.97^{\mathrm{e}}$ \\
extract $+\mathrm{CCl}_{4}$ & & & \\
$400 \mathrm{mg} / \mathrm{kg} \mathrm{b} . w t$ & $197.45 \pm 2.10^{\mathrm{d}}$ & $206.75 \pm 1.89^{\mathrm{d}}$ & $244.45 \pm 1.75^{\mathrm{d}}$ \\
extract $+\mathrm{CCl}_{4}$ & & & \\
$600 \mathrm{mg} / \mathrm{kg} \mathrm{b} . w t$ & $171.36 \pm 2.11^{\mathrm{C}}$ & $170.00 \pm 5.10^{\mathrm{c}}$ & $226.66 \pm 3.69^{\mathrm{c}}$ \\
extract $+\mathrm{CCl}_{4}$ & & & \\
$800 \mathrm{mg} / \mathrm{kg} \mathrm{b} . w t$ & $100.56 \pm 1.63^{\mathrm{a}}$ & $138.00 \pm 5.66^{\mathrm{a}}$ & $169.15 \pm 4.03^{\mathrm{a}}$ \\
extract $+\mathrm{CCl}_{4}$ & & & \\
\hline
\end{tabular}

Values are mean $\pm \mathrm{SD}, \mathrm{n}=4$. Values in the same column having different superscripts differ significantly $(\mathrm{p}<0.05)$; CK $=$ Creatine kinase; $\mathrm{LDH}=$ Lactate dehydrogenase; AST $=$ Aspartate transaminase

\subsection{Effects of Costus afer Leaf Extract on Serum Lipid Profile}

Effect of Costus afer leaf extract on serum lipid profile of $\mathrm{CCl}_{4}$ intoxicated rats is summarized in Table 3. The serum levels of TAG, TC, and LDL significantly ( $\mathrm{p}<$
0.05) increased in $\mathrm{CCl}_{4}$ intoxicated rats while drastic significant $(\mathrm{p}<0.05)$ decrease in HDL was observed compared to the control group. However, treatment with aspirin and Costus afer leaf extract significantly $(\mathrm{p}<0.05)$ improved the lipid profile, decreasing triacylglycerol, total cholesterol and LDH levels to near normal as compared to $\mathrm{CCl}_{4}$ treated group while $\mathrm{HDL}$ level was significantly $(\mathrm{p}<0.05)$ increased. The effect of Costus afer extract on lipid profile at dose of $800 \mathrm{mg} / \mathrm{kg}$ was significantly more effective when compared to aspirin.

\subsection{Effect of Costus afer Leaf Extract on Cardiac Enzymatic Antioxidant Levels}

Result of the evaluation of the antioxidant activity of the extract is presented in Table $4 . \mathrm{CCl}_{4}$ intoxication markedly suppressed the antioxidative status of cardiac SOD, catalase, and glutathione reductase relative to the control group. Administration of aspirin and graded doses of the extract significantly $(\mathrm{p}<0.05)$ amended the toxic effect of $\mathrm{CCl}_{4}$ by improving the activities of the suppressed antioxidant enzymes.

Table 3. Result of serum lipid profile of the animals

\begin{tabular}{lccccc}
\hline Group & (TAG) $(\mathrm{mmol} / \mathrm{L})$ & $\mathrm{TC}(\mathrm{mmol} / \mathrm{L})$ & $(\mathrm{LDL})(\mathrm{mmol} / \mathrm{L})$ & $\mathrm{HDL}(\mathrm{mmol} / \mathrm{L})$ & Artherogenic Index \\
\hline Normal Control & $1.43 \pm 0.03^{\mathrm{b}}$ & $4.03 \pm 0.03^{\mathrm{a}}$ & $1.12 \pm 0.06^{\mathrm{ab}}$ & $1.79 \pm 0.10^{\mathrm{e}}$ & 0.63 \\
$\mathrm{CCl}_{4}$ only & $1.71 \pm 0.03^{\mathrm{f}}$ & $4.94 \pm 0.05^{\mathrm{d}}$ & $2.78 \pm 0.14^{\mathrm{f}}$ & $1.30 \pm 0.03^{\mathrm{a}}$ & 2.14 \\
$1.2 \mathrm{mg} / \mathrm{kg}$ aspirin $+\mathrm{CCl}_{4}$ & $1.55 \pm 0.02^{\mathrm{c}}$ & $4.17 \pm 0.06^{\mathrm{ab}}$ & $1.20 \pm 0.01^{\mathrm{bc}}$ & $1.69 \pm 0.03^{\mathrm{d}}$ & 0.71 \\
$200 \mathrm{mg} / \mathrm{kg}$ b.wt extract $+\mathrm{CCl}_{4}$ & $1.64 \pm 0.03^{\mathrm{e}}$ & $4.80 \pm 0.02^{\mathrm{d}}$ & $2.35 \pm 0.04^{\mathrm{e}}$ & $1.42 \pm 0.09^{\mathrm{b}}$ & 1.66 \\
$400 \mathrm{mg} / \mathrm{kg}$ b.wt extract $+\mathrm{CCl}_{4}$ & $1.60 \pm 0.02^{\mathrm{e}}$ & $4.51 \pm 0.35^{\mathrm{c}}$ & $1.98 \pm 0.08^{\mathrm{d}}$ & $1.54 \pm 0.04^{\mathrm{c}}$ & 1.29 \\
$600 \mathrm{mg} / \mathrm{kg}$ b.wt extract $+\mathrm{CCl}_{4}$ & $1.56 \pm 0.04^{\mathrm{cd}}$ & $4.44 \pm 0.10^{\mathrm{bc}}$ & $1.23 \pm 0.02^{\mathrm{c}}$ & $1.63 \pm 0.05^{\mathrm{d}}$ & 0.76 \\
$800 \mathrm{mg} / \mathrm{kg}$ b.wt extract $+\mathrm{CCl}_{4}$ & $1.37 \pm 0.02^{\mathrm{a}}$ & $3.89 \pm 0.33^{\mathrm{a}}$ & $1.05 \pm 0.01^{\mathrm{a}}$ & $1.83 \pm 0.03^{\mathrm{e}}$ & 0.57 \\
\hline
\end{tabular}

Values are mean $\pm \mathrm{SD}, \mathrm{n}=4$. Values in the same column having different superscripts differ significantly $(\mathrm{p}<0.05)$; TAG $=$ Triglyceride; $\mathrm{TC}=$ total cholesterol; LDL = low density lipoprotein; HDL = high density lipoprotein; $\mathrm{AI}=$ arterogenic index.

Table 4. Result of heart levels of CAT, SOD and GR

\begin{tabular}{lccc}
\hline Groups & SOD (U/L) & CAT (U/L) & GR (u/mg protein) \\
\hline Normal control & $11.08 \pm 0.13^{\mathrm{f}}$ & $7.47 \pm 0.12^{\mathrm{f}}$ & $28.88 \pm 0.34^{\mathrm{f}}$ \\
$\mathrm{CCl}_{4}$ only & $10.22 \pm 0.04^{\mathrm{a}}$ & $2.62 \pm 0.08^{\mathrm{a}}$ & $22.50 \pm 0.28^{\mathrm{a}}$ \\
$1.2 \mathrm{mg} / \mathrm{kg}$ aspirin $+\mathrm{CCl}_{4}$ & $10.38 \pm 0.05^{\mathrm{d}}$ & $6.09 \pm 0.15^{\mathrm{e}}$ & $27.36 \pm 0.40^{\mathrm{e}}$ \\
$200 \mathrm{mg} / \mathrm{kg}$ b.wt extract $+\mathrm{CCl}_{4}$ & $10.78 \pm 0.02^{\mathrm{b}}$ & $3.57 \pm 0.16^{\mathrm{c}}$ & $24.67 \pm 0.34^{\mathrm{c}}$ \\
$400 \mathrm{mg} / \mathrm{kg}$ b.wt extract $+\mathrm{CCl}_{4}$ & $10.47 \pm 0.04^{\mathrm{b}}$ & $4.34 \pm 0.22^{\mathrm{c}}$ & $25.61 \pm 0.57^{\mathrm{c}}$ \\
$600 \mathrm{mg} / \mathrm{kg}$ b.wt extract $+\mathrm{CCl}_{4}$ & $10.67 \pm 0.06^{\mathrm{c}}$ & $5.33 \pm 0.10^{\mathrm{d}}$ & $26.25 \pm 0.18^{\mathrm{d}}$ \\
$800 \mathrm{mg} / \mathrm{kg}$ b.wt extract $+\mathrm{CCl}_{4}$ & $10.93 \pm 0.07^{\mathrm{e}}$ & $6.70 \pm 0.24^{\mathrm{e}}$ & $28.53 \pm 0.33^{\mathrm{f}}$ \\
\hline
\end{tabular}

Values are mean $\pm S D, n=4$. Values in the same column having different superscripts differ significantly $(\mathrm{p}<0.05)$ 


\subsection{Effect of Costus afer Leaf Extract on Lipid Peroxidation}

Evaluated level of malondialdehyde content in heart homogenate is shown in Figure 1. MDA content in heart homogenate was significantly $(\mathrm{p}<0.05)$ increased in $\mathrm{CCl}_{4}$ group compared to the normal control. Treatment with aspirin and Costus afer leaf extract significantly $(\mathrm{p}<0.05)$ decreased MDA level in a dose dependent manner relative to the $\mathrm{CCl}_{4}$ intoxicated group. Markedly, at a dose of 800 $\mathrm{mg} / \mathrm{kg}$ b.w, Costus afer extract showed a more potent effect when compared to the standard drug, aspirin.

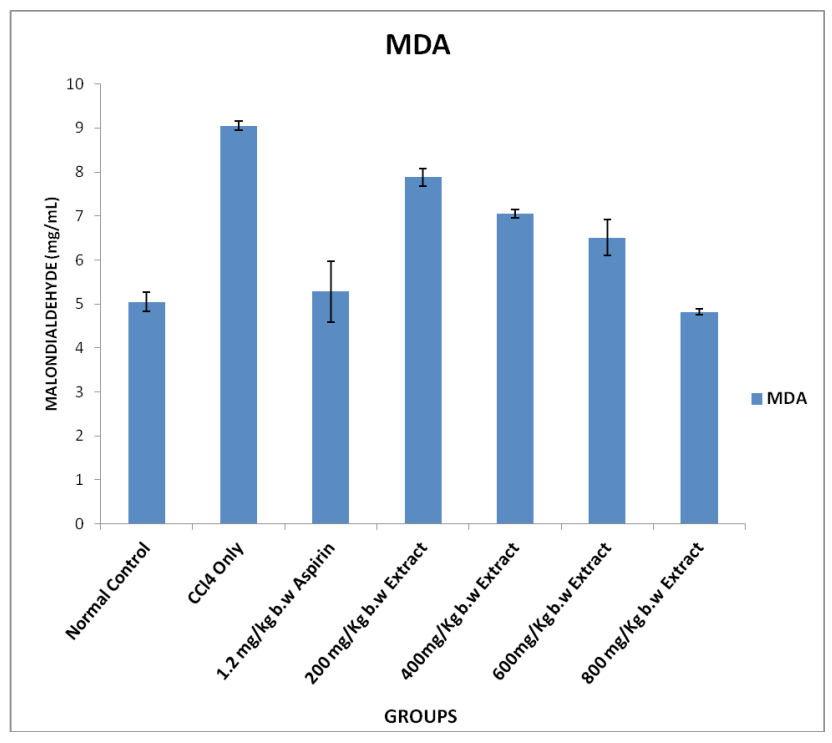

Figure 1. Decreased levels of MDA caused by Costus afer leaf extract.

\section{Discussion}

The presence of alkaloids, flavonoids, saponins, tannins, terpenoids, cardiac glycosides, phenols, and sterols in substantial quantities (Table 1), agrees with previous studies of Momoh et al. and Akpabio et al ${ }^{13,27}$. Phenolic compounds are a class of antioxidant agents which act as free radical terminators, and their bioactivities may be related to their abilities to chelate metals, inhibit lipoxygenase and scavenge free radicals ${ }^{28}$. The scavenging effect of free radical by various constituents of plants may be due to phenolic acids and flavonoids ${ }^{29}$. Similarly, terpenoids, as vitamins, act as regulators of metabolism and play a protective role as antioxidants ${ }^{30}$. Flavonoids, phenols and terpenoids present in the extract possibly indicate beneficial antioxidant properties of Costus afer leaf extract. Cardiac glycosides inhibits $\mathrm{Na}^{+} / \mathrm{K}^{+}$pump causing an increase in concentration of $\mathrm{Ca}^{+}$for heart muscle contraction thereby improving cardiac output and reduces distention of the heart; thus, help in the treatment of congestive heart failure and cardiac arrhythmia ${ }^{31}$. Sterol is a group of natural steroid alcohols. Plant steroids are known to be important for their cardio toxic activity. Cardiac glycosides and sterol present in the extract may be suggested to exert cardio protective effects. As cardiac tissue has affinity for $\mathrm{CCl}_{4}$ due to $\mathrm{Cyt} \mathrm{P}_{450}$, oxidative damage to lipids and proteins of heart tissues probably occurred due to $\mathrm{CCl}_{4}$ intoxication. ${ }^{32}$ An approach for detection of cardiac injury, tissue ischemia and myocardial infarction involves measurements of the cardiac marker enzymes for example, Creatine Kinase (CK), cardiac Creatine Kinase-MB fraction (CK-MB), AST, ALT, ALP and LDH in serum ${ }^{33,34}$. The integrity of cardiac cell membrane gets disrupted as a consequence of peroxidation of membrane by oxygen derived free radicals ${ }^{35}$. Significant increases in serum Cardiac Marker enzymes (CK, AST and LDH) observed in the group treated with $\mathrm{CCl}_{4}$ alone indicates damage to the myocardial cell membrane, consequently leading to the leakage of cytosolic contents of the cell into the plasma. The ability of the extract to reverse $\mathrm{CCl}_{4}$ toxic effect suggests protective effect on cardiac marker enzymes. This cardio protection may be attributed to the ability of the bioactive compounds in the extract to chelate the by-products of $\mathrm{CCl}_{4}$ metabolism, hence, scavenging reactive oxygen species reaction. Moreover, previous studies have reported that the oxidative damage to tissues and their cellular components can be prevented by certain antioxidant metabolites present in the plants ${ }^{36}$. This could be a characteristic of the plant that justifies its use in the management of disease conditions in the folklore medicine of Nigeria.

Changes in the levels of major lipids such as TAG, TC, LDL-C and HDL-C could give useful information on the predisposition of the heart of animals to artherosclerosis and its associated coronary heart. TAG, LDL and HDL are associated with lipolysis, transport of plasma cholesterol and artherosclerotic tendency respectively ${ }^{37}$. Increase in serum lipid profile of the animals intoxicated with $\mathrm{CCl}_{4}$ only prognosticates cardiovascular risk. Reduction in the levels of TAG, TC, LDL-C and increase in HDL-C observed amongst the groups treated with aspirin and graded doses of the extract suggested unsusceptibility to cardiovascular risk. In this present study, Costus afer 
leaves extract may be suggested to possess antiatherogenic capacity.

Malondialdehyde (MDA) is one the final products of polyunsaturated fatty acids peroxidation in the cells and is commonly known as a lipid peroxidation marker of oxidative stress ${ }^{38}$. Overproduction of MDA is caused by increase in free radicals. The increase in MDA content of heart tissues of $\mathrm{CCl}_{4}$ intoxicated animals indicated that peroxidation of polyunsaturated fatty acids in the cardiac cell membrane have occurred. This also buttressed the disruption of the integrity of the cardiac cell membrane observed earlier. Significant decreases in cardiac MDA content following the administration of aspirin and graded doses of the extract confirmed that treatment with the extract could have a great protective effect against the $\mathrm{CCl}_{4}$-induced cardiac lipid peroxidation. This protective effect of Costus afer extract on lipid peroxidation that occurs deep within the membrane bilayer may be attributed to some of its antioxidant components. Consequently, could promote membrane stabilization and restore altered biochemical profiles induced by $\mathrm{CCl}_{4}$ exposure. Glutathione reductase is a flavoprotein that permits the conversion of oxidized glutathione (GSSG) to reduced Glutathione (GSH) by the oxidation pf $\mathrm{NADPH}$ to $\mathrm{NADP}^{+39}$. Glutathione, the first line defense against ROS, is a readily available source of endogenous sulfhydryl $(-\mathrm{SH})$ groups $^{40}$. Inactivation of glutathione reductase in the heart leads to the accumulation of GSSG and increases the susceptibility of myocardial membrane to reactive oxygen metabolites and lipoperoxidation necrotic damage ${ }^{41-43}$. Significant decline in cardiac level of glutathione reductase observed in the $\mathrm{CCl}_{4}$ intoxicated rats demonstrated enhanced oxidative stress which may be attributed to the direct conjugation of $\mathrm{CCl}_{4}$ metabolites with free or bound -SH groups thereby interfering with the antioxidant functions. Rats treated with aspirin and graded doses of Costus afer leaves extract demonstrated abridged lipid peroxidation with enhanced glutathione reductase activity. Thus, promoting the regeneration of reduced glutathione for normal cell metabolism. This cardioprotective effect of the extract and aspirin may be attributed to the terpenoids and cardiac glycosides constituents of the extract coupled with its antioxidant propensity.

The activities of CAT, SOD are significantly reduce in GSH depleted conditions due to pronounced oxidative stress and accumulation of $\mathrm{H}_{2} \mathrm{O}_{2}$ making the cells more vulnerable to oxidative stress ${ }^{44}$. The antioxidant activity or the inhibition of the generation of free radicals is important in providing protection against myocardial infarction ${ }^{8}$. The reduction in the levels of antioxidant enzymes (SOD and CAT) following the administration of $\mathrm{CCl}_{4}$ alone indicates the overwhelming of the antioxidant defence system by $\mathrm{CCl}_{4}$ metabolites thus predisposing the cardiac tissue to increased free radical damage. The significantly augmented endogenous antioxidant enzymes following the administration of aspirin and the extract suggested that free radicals were prevented from overpowering the antioxidant defence system. These are indications of antioxidant potentials of the extract of Costus afer leaves and aspirin.

\section{Conclusion}

The present study concludes that protective effects of Costus afer leaf extract against $\mathrm{CCl}_{4}$-induced cardio toxicity in rats are attributed to its antioxidant components, contributing to total antioxidant defence system, and promoting cell membrane stabilization in toxin-induced cellular damage. Costus afer leaf extract may be one of the possible protective and therapeutic agents for augmenting defence mechanisms against oxidative stress caused during myocardial infarction.

\section{Acknowledgements}

We are thankful to Mr. A. Mbaoji for all his technical assistance.

\section{References}

1. Karamian R, Fatemeh G. Screening of total phenol and flavonoid content antioxidant and antibacterial activities of the methanolic extracts of three Silene species from Iran. Intl J Agri Crop Sci. 2013; 5(3):305-12. Available from: www.ijagcs.com IJACS/2013/5-3/305-312

2. World Health Organization. General guidelines for the methodologies on research and evaluation of traditional medicine. Geneva, Switzerland: WHO; 2001.

3. Dhalla NS, Elmosielli AB, Hata, T, Makino N. Status of myocardial antioxidants in ischemia-reperfusion injury. Cardiovasc. Res. 2000; 47:446-56. Available from: https:// doi.org/10.1016/S0008-6363(00)00078-X

4. Hearse DJ. Prospects for antioxidant therapy in cardiovascular medicine. Am J Med. 1991; 91:1185-215. Available from: https://doi.org/10.1016/0002-9343(91)90294-8 
5. Liu SO, Yu JP, Chen HL, Luo HS, Chen SM. and Yu HG. Therapeutic effects and molecular mechanisms of Ginko biloba extract on liver fibrosis in rats. American J Chin Med. 2006; 34:99-114. PMid:16437743. Available from: https://doi.org/10.1142/S0192415X06003679

6. Ichikawa H, Wang L, Konishi T. Prevention of cerebral oxidative injury by post ischemic intravenous administration of Shengmai San. American J Chin Med. 2006; 34:591-600. PMid:16883630. Available from: https://doi.org/10.1142/ S0192415X06004120

7. Khan RA. Protective effects of Launaea procumbens on rats' testis damage by CCl4. Lipids Health Dis. 2012; 11:103. DOI: 10.1186/1476-511X-11-103. Available from: https:// doi.org/10.1186/1476-511X-11-103

8. Khan RA, Khan MR, Sahreen S. Protective effects of Sonchus asper against $\mathrm{KBrO} 3$ induced lipid peroxidation in rats. Lipids Health Dis.2012; 11(1):164. DOI: 10.1186/1476-511X-11-164. Available from: https://doi. org/10.1186/1476-511X-11-164

9. Khan RA. Protective effect of Sonchus asper (L) Hill (Asteraceae) against CCl4-induced oxidative stress in the thyroid tissue of rats. BMC Complement Altern Med. 2012; 12:181. DOI: 10.1186/1472-6882-12-181. Available from: https:// doi.org/10.1186/1472-6882-12-181

10. Iwu MM. Handbook of African medicinal plants. London: CRC; 1993.

11. Aweke. Costus afer ker Gawl. Record from PROTA4U. In: Schmeizer G. H, Gurib-Fakim, A, editors. PROTA (Plant Resources of Tropical Africa/Resources Vegetables de L' Afrique Tropicale. Netherlands: Wageningen; 2007. Available from: http://www.prota4u.org/search.asp

12. Momoh S, Yusuf OW, Adamu MM, Agwu COC, Atanu FO. Evaluation of the phytochemical composition and hypoglycemic activity of methanolic leaves extract of Costus afer in albino rats. Br J Pharm Res.2001; 1(1):1-8. Available from: https://doi.org/10.9734/BJPR/2011/237

13. Anyasor GN, Funmilayo DO, Odutola O, Olugbenga A, Bawo O, Efere MO. Chemical constituents in n-butanol fractions of Costus afer ker Gawl leaf and stem. J intercult ethnopharmacol. 2014; 3(2):78-84. DOI: 10.5455/ jice.20140112010648. Available from: https://doi. org/10.5455/jice.20140112010648

14. Omokhua GE. Medicinal and socio-cultural importance of Costus afer (ker Gawl) in Nigeria. Afr Res. 2011; 5(5):282-7.

15. Anyasor GN, Funmilayo DO, Odutola O, Olugbenga A. Hematological and lipid profile evaluation of a hexane fraction of Costus afer leaves in arthritic rats. Pharm Biol. 2014; 53(11):1671-6. PMid:25857603. Available from: ttps://doi. org/10.3109/13880209.2014.1001404

16. Taiwo AO, Bolanle AA. The leaf essential oil of Costus afer ker Gawl from Nigeria. Flavour Frag J. 2013; 18(4):309-311. Available from: https://doi.org/10.1002/ff.1186

17. Harborne JB. Phytochemical methods: A guide to modern techniques of plant analysis. London: Chapman and Hall Ltd; 1973.
18. Trease GE, Evans WC. Pharmacognosy. 15th ed. London: Saunder Publisher; 2002.

19. Harborne JB. Phytochemical methods: A guide to modern technique of plant analysis. London: Champman and Hall; 1998. PMid:28308423

20. Arumugam P, Ramamurthy P, Santhiya ST, Ramesh A. Antioxidant activity measured in different solvent fractions obtained from Mentha spicata Linn: An analysis by ABTS $^{*}+$ decolorization assay. Asia Pac J Clin Nutr. 2006; 15(1):119-24. PMid:16500887

21. Agbafor KN, Ezeani C, Akubugwo EI, Obiudu IK, Uraku AJ, Ogbanshi ME, Edwin N, Ugwu OPC. Cardioprotective effect of leaf and root extracts of Newbouldia leavis against carbon tetrachloride induced-cardiotoxicity in Albino Rats. European J Med. Plants. 2015; 9(3):1-7. Available from: https://doi.org/10.9734/EJMP/2015/17673

22. Ohkawa H, Ohishi N, Yagi K. Assay for lipid peroxide in animal tissues by thiobarbituric acid reaction. Annal Biochem. 1979; 95:51-5. Available from: https:/doi. org/10.1016/0003-2697(79)90738-3

23. Kakkar P, Das B, Viswanathan PN. Modified spectrophotometric assay of superoxide dismutase (SOD). Indian J. Biochem. Biophys. 1984; 2:130-2.

24. Aebi H. Catalase: In: Bergmeyer, Hv eds. Methods in enzymatic analysis analysis. New York: Academic Press Inc; 1994. PMCid:PMC44120

25. Bentler E. Effect of flavin compounds on glutathione reductase activity: In vivo and In Vitro Studies. J Clin Invest. 1975; 48:1957-66. PMid:5822598 PMCid:PMC322432. Available from: https://doi.org/10.1172/JCI106162

26. Akpabio UD, Udo UE, Akpankpan AE. Evaluation of phytochemical, proximate and mineral element composition of stem of Costus afer. Asian J Plant Sci Res. 2012; 2:607-12.

27. ShalidiF,JanithaPK, WanasundaraSD.Phenolicantioxidants. Crit Rev Food Sci Nutr. 1992; 32:67-103. PMid:1290586. https://doi.org/10.1080/10408399209527581

28. Boumerfeg S, Baghiani A, Messaoudi D, Khennouf S, Arrar L. Antioxidant properties and xanthine oxidase inhibitory effects of Tamus communis L root extracts. Phytother Res. 2009; 23:283-8. PMid:18844260. Available from: https:// doi.org/10.1002/ptr.2621

29. Soetan KO. Pharmacological and other benefits of antinutritional factors in plants. A Review. Afr J Biotechnol. 2008; 7(25):4713-21.

30. Denwick PM. Natural product: A biosynthetic approach. 2nd ed. England: John Wiley and Sons Ltd; 2002.

31. Sahreen S, Khan MR, Khan RA, Alkreathy HM. Cardioprotective role of leaves extract of Carissa opaca against CCl4-induced toxicity in rats. BMC Res Notes. 2014; 7:224. PMid:24716654 PMCid:PMC3983670. Available from: https://doi.org/10.1186/1756-0500-7-224

32. Chrostek L, Szmitkowski M. Enzymatic diagnosis of alcoholism-induced damage of internal organs. Psychiatr Pol. 1989; 23(5-6):353-60. PMid:2577212.

33. Mair J. Cardiac troponin 1 and troponin T: Are enzymes still 
relevant as cardiac markers? Clinica Chimica Acta. 1997; 257(1):99-115. Available from: https://doi.org/10.1016/ S0009-8981(96)06436-4

34. Adams JE, Abendschein DR, Jaffe AS. Biochemical markers myocardial injury. Is $\mathrm{MB}$ creatine kinase the choice for 1990s? Circul. 1994; 88:750-63. Available from: https://doi. org/10.1161/01.CIR.88.2.750

35. Khan MR, Ahmed D. Protective effect of Digera muricata (L.) mart on testis against oxidative stress of $\mathrm{CCl} 4$ in rats. Food Chem Toxicol. 2009; 47(6):1393-3. PMid:19327381. Available from: https://doi.org/10.1016/j.fct.2009.03.020

36. Yakubu MT, Akanji, MA, Oladeji AT. Alternations in serum lipid profile of male rats by oral administration of aqueous extract of Fadogia agrestis stem. Res J Med Plants. 2008; 2:66-73. Available from: https://doi.org/10.3923/ rjmp.2008.66.73

37. Gawel S, Wardao M, Niedworok, Wardas P. Malondialdehyde (MDA) as a lipid peroxidatiion marker. Wiad Lek. 2004; 57(9-10):453-5. PMid:15765761

38. Papas AM. Other antioxidant. In: Antioxidant status, diet, nutrition, and health. Papas AM, editor. Boca Raton, FL: CRC Press; 1998. p. 231-48. PMid:10578093.

39. Shanmugarajan TS, Devaki T. Ficus hispida Linn. Leaf extract possesses antioxidant potential and abrogates azathio- prine induced prooxidant and antioxidant imbalance in rat liver. Int J Pharm. 2008; 4: 376-81. Available from: https:// doi.org/10.3923/ijp.2008.376.381

40. Ferrari R, Ceconi C, Cerelto S, Guarnieri CM, Albertini A, Visidi D. Oxygen mediated myocardial damage using ischemia and reperfusion: Role of cellular defences against oxygen toxicity. J Mol Cell Cardiol. 1985; 17:937-45. Available from: https://doi.org/10.1016/S0022-2828(85)80074-2

41. Anandan R, Asha KK, Ammu K, Matthew S, Nair PG. Effects of peroxidized PUFA on tissue defense system in experimentally induced myocardial infarction in rats. In: Seafood safety society of fisheries technologists. Surendran PK, Matthew PT, Thampuran N, Nambiar N, Joseph J, Booopendranath MR, Lakhsmanan PT, Nair PGV, editor. Cochin India; 2003. p. 330-5.

42. Ojha S, Bhatia J, Arora S, Golechha M, Kumari S, Arya DS. Cardioprotective effects of Commiphora mukul against isoprenaline-induced cardiotoxicity: A biochemical and histopathological evaluation. J Env Biol. 2011; 32(6):731-8. PMid:22471209.

43. Rajasekaran NS, Devaraj H, Devaraj SN. The effect of Glutathione Monoester (GME) on glutathione (GSH) depleted rat liver. J Nutr Biochem. 2002; 13:302-6. Available from: https://doi.org/10.1016/S0955-2863(01)00223-6 